\title{
Characterization of Opaques off Konkan Coast Maharashtra, Central West Coast of India
}

\author{
Gujar, A.R ${ }^{1}$, Angusamy, $N^{2}$, and Rajamanickam, G. $V^{3}$ \\ ${ }^{1}$ National Institute of Oceanography, Dona Paula, Goa, India - 403004. \\ Email: agujar@nio.org \\ ${ }^{2}$ Dept. of Earth Sciences, Tamil University, Thanjavur, India - 613 005. Email: \\ angu1@yahoo.com \\ ${ }^{3}$ Disaster Management, SASTRA Deemed University, Thanjavur, India - 613402. \\ Email:vrajamanickam@yahoo.com
}

\begin{abstract}
Characterisation of opaques, comprising of ilmenites and magnetites, separated from the sediment samples off Konkan coast, has been attempted. On the basis of dominance of intergrowth of the exsolved or replaced phases, magnetites of Vijayudurg and Wada vetye are grouped together while the magnetites of Ambolgarh and Rajapur are showing similar characteristics. Ilmenites display intergrowths with hematite and rutile. In Ambolgarh and Rajapur, ilmenites of exsolved and replacement phases are abundant with alterations along the borders. On the basis of intergrown lamellae width, the source rock for the ilmenites is attributed to the distant metamorphic rocks
\end{abstract}

The presence of altered ilmenites testify a higher percentage of $\mathrm{TiO}_{2}$ in Ambolgarh and Rajapur. A higher amount of $\mathrm{FeO}$ (35.79 \% - $36.25 \%$ ) in Wada Vetye and Vijaydurg is ascribed to higher percentage of ilmenite - hematite phase in the exsolved ilmenites. REE pattern of ilmenites, magnetites and non-magnetics show an enrichment of LREE over HREE. Ilmenite, magnetite and non-magnetics show a negative Eu anomaly which is ascribed to the individual or combination of the following conditions: 1) Melt effect, 2) Crystallo-Chemical effect, and 3) Competing mineral effect. A higher enrichment of $\mathrm{TiO}_{2}$ in the ilmenites reflects the possibility of establishing down-stream industries as well as the suitability for converting ilmenites into synthetic rutile.

Key Words : Opaques, Intergrowth, REE, India.

\section{INTRODUCTION}

The world reserves of economic sources of titanium are estimated to be approximately 300 million tons that contained $\mathrm{TiO}_{2}$ [1]. Major resources occur in 
Australia, Canada, China, India, New Zealand, Norway, South Africa, Ukraine, and the United States. World production figures of titanium minerals indicate that $55 \%$ production is made available from shoreline deposits and the rest $45 \%$ from the magmatic source (Force, 1980). The demand for ilmenite is driven, to a large extent, by growth in demand for $\mathrm{TiO}_{2}$ pigments. $\mathrm{TiO}_{2}$ pigment is mainly used in the Paints \& Coatings (59 \%), Plastics (20\%) and Paper (13\%) industries [2].

Trends such as use of bright glossy finishes in paints, higher demand for light paper, increased paper recycling, and substitution of traditional materials with plastics, on substantial scale, correlate to a growing demand for $\mathrm{TiO} 2$ pigment in these application areas. Of the total global inferred reserves of 1418 million tones of titanium minerals, India has a reserve of about 348 million tones [3]. However, when the production of ilmenite is looked into, the ratio of production of ilmenite to the reserves is only $0.1 \%$ while the countries such as Malaysia (7\%), USA (3\%), Australia (1\%) and Brazil (1.8\%) keep better ratio [1].

India is blessed with large reserves of strategic and economically important heavy minerals such as leucoxene, zircon, monazite, ilmenite, rutile, garnet and sillimanite. In India, a two stage model for pseudo-rutile formation from the ilmenites of Manavalakurichi region has been reported [4] and the alteration of ilmenites from the river Valliyar and Manavalakurichi beach has been outlined [5]. Along the Ratnagiri coast, the provenance of offshore ilmenite placers, based on geochemical studies has been dealt in detail [6,7]. From South India, a detailed account of alteration characteristics of ilmenites has been enunciated [8]. However, characterization of opaque minerals is not yet attempted from the present study region. The present work highlights the distribution pattern of intergrowths of opaque minerals viz., ilmenite and magnetite and their chemical compositions for exploitation.

\section{STUDY AREA}

From the Konkan coast, only four southern bays viz; Wada Vetye, Ambolgarh, Rajapur and Vijaydurg have been taken up for the present study. These bays with Wada Vetye in the North, and Vijaydurg in the South (Fig.1) are bounded by submergent type of coastline, which is very irregular and indented. Wadavetye bay is a straight and promontories in the North and South.

The Ambolgarh bay is gentle, arcuate to semi arcuate in shape. The Rajapur bay has small pocket bay behind the promontory, whereas the Vijaydurg has an arcuate bay (Table 1). The Ambolgarh bay is a protected zone and does not have any river or stream source.

\section{MATERIALS AND METHODS}

A van Veen grab $\left(0.04 \mathrm{~m}^{2}\right.$ scoop area) was used for the collection of surface sediment sample (116 Nos) from the near shore region of the Konkan coast (up to 20 $\mathrm{m}$ water depth). Samples were washed and dried. After coning and quartering, carbonates, organic matter and ferruginous coatings were removed from the samples 


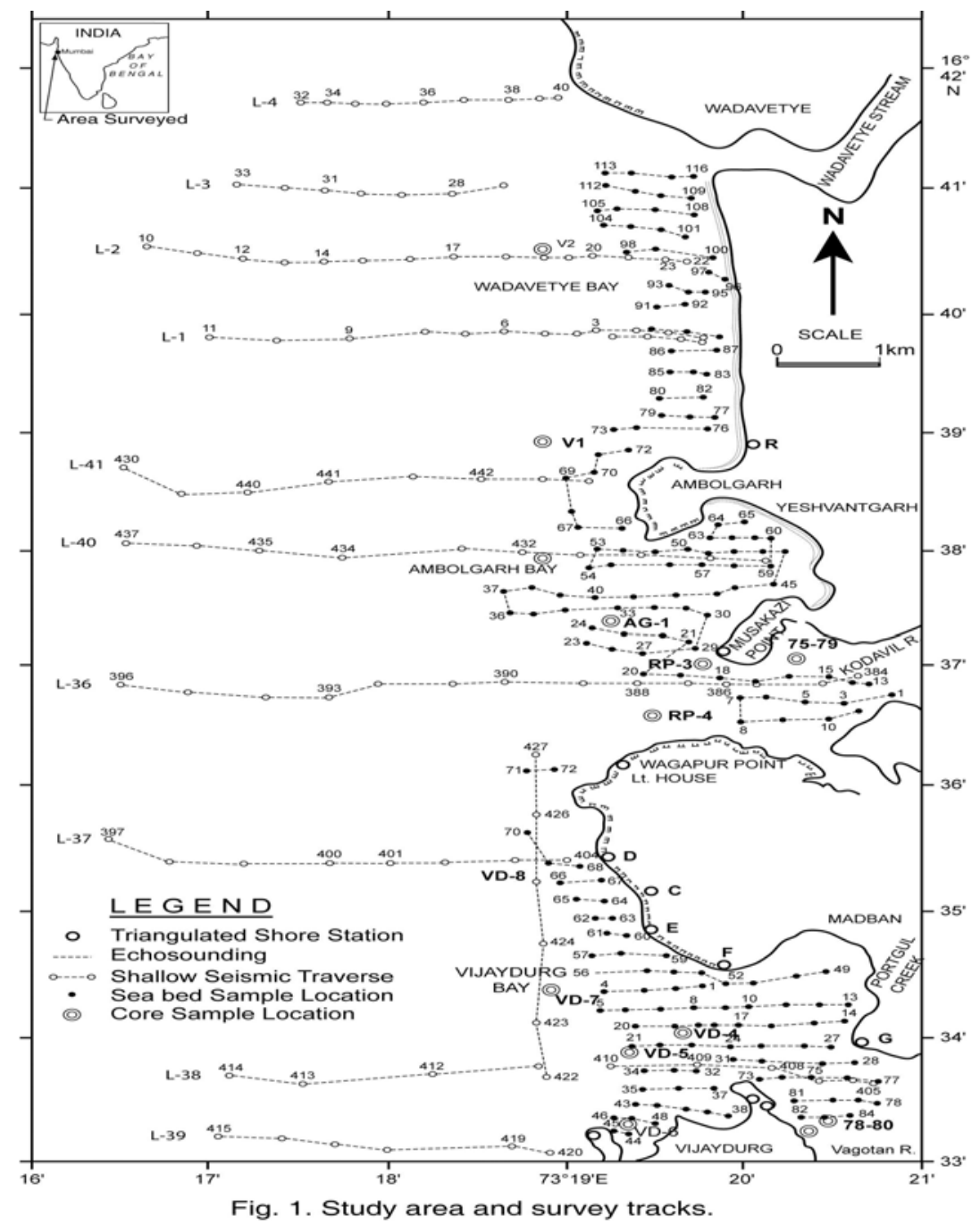

Table 1: Characteristics features of the bays

\begin{tabular}{|l|l|l|l|l|}
\hline Bays & vijayadurg & Rajapur & Ambolgarh & WadaVetye \\
\hline Shape & Arcuate & Arcuate & $\begin{array}{l}\text { Arcuate to } \\
\text { semiarcuate }\end{array}$ & Staright \\
\hline $\begin{array}{l}\text { Coastline } \\
\text { configuration }\end{array}$ & NNE-SSW & E-W & NE-SW & N-S \\
\hline Promotionaries & N \& S & N \& S & S & S \\
\hline Beach & Sandy & sandy & Sandy & $\begin{array}{l}\text { Bouldery and } \\
\text { coarse sand }\end{array}$ \\
\hline Wind & $\begin{array}{l}\text { Partially } \\
\text { protected }\end{array}$ & $\begin{array}{l}\text { Partially } \\
\text { protected }\end{array}$ & Protected & Open condition \\
\hline Lnadforms & $\begin{array}{l}\text { Sandbar- } \\
\text { Mudflats and } \\
\text { Mangroves }\end{array}$ & Sandy beach & Tombolo & $\begin{array}{l}\text { Bouldery beach } \\
\text { (N) }\end{array}$ \\
\hline
\end{tabular}


by treatment with $1: 10 \mathrm{HCl}, 30 \%$ by volume $\mathrm{H}_{2} \mathrm{O}_{2}$ and $\mathrm{SnCl}_{2}$, respectively. The dry samples were sieved at Ro-Tap sieve shaker for 15 minutes. Heavy mineral separation was carried out by using a bromoform of 2.89 specific gravity [9].

Ilmenites were removed using the Cook isodynamic separator, having the forward slope of $15^{\circ}$ and a side tilt of $10^{\circ}$ at 0.2 Amp. The separation was confirmed by X-ray diffraction on a Philips PWG. 1840 Powder diffractometer. Representative detrital ilmenites (8 Nos) and magnetites ( 8 Nos), covering the bays, were mounted on a bakelite medium and after polishing, under reflected light, examined for their nature of intergrowths and exsolution structure, etc. Chemical analysis of representative ilmenite (8 Nos) and magnetite (8 Nos) was done by preparing single solution [10,11] using GBC - UV Visible Spectrophotometer. Ferrous oxide determination was done by titration method [12]. Trace and REE analyses (ilmenite 8 Nos, Magnetite 8 Nos and Non-magnetics - 2 Nos) were carried out in ICP - Mass Spectrometer [13].

\section{RESULTS AND DISCUSSION}

Under microscope, magnetites of Wada Vetye bay shows almost an equidistribution of magnetite + hematite and magnetite + ilmenite ( Fig.2 A). In addition, magnetites show exsolution texture with hematite (Fig.3 A), ilmenite or ulvo-spinel, hematite or sphene and rutile. Titano-magnetites are criss-crossed by exsolved rutile needles (Fig.3 B).

Ambolgarh bay is marked by the domination of pure magnetite (Fig. 2 A). However, irregular grains are marked by the development of martites along the border (Fig.3 C). Titanomagnetites with ilmenite and martites along the borders are also noticeable (Fig. 3 D). Magnetites with exsolution and replacement textures and sphene are insignificant. In Rajapur, again pure unexsolved magnetites with maghemeite, are dominant (Fig. 3 E). However, magnetites, intergrown with hematite, prevail over magnetite + ulvo-spinel + hematite and rutile, higher than other bays (Fig. 3 F, G, H, I, J, and K). Broadly, Vijaydurg and Wada vetye can be grouped together while Ambolgarh and Rajapur can be clustered together (Fig.2 A).

Ilmenite shows intergrowth textures with hematite and rutile (Fig.3 L). Among them, seriate type of intergrowth is preponderant in Ambolgarh and Rajapur bays. In the seriate texture, the thickness of exsolved ilmenite or hematite is not uniform, since the exsolution bodies grow by diffusion. In few ilmenites, broad lamellae of hematite are alternately arranged parallel to each other without the intercalation of other phases. Large grains of ilmenite show lamellar twinning including rutile needles along (0001) and (0011) planes (Fig. $3 \mathrm{M}$ ). Ilmenite grains are also characterized by alteration along the boundaries.

In Ambolgarh, ilmenites are subrounded, showing dominant replacement texture by secondary hematite and rutile (Fig.2 B). These forms are free from any coatings. Besides, exsolution with hematite and rutile, it is replaced along the border 
by sphene (Fig.3 N). In the exsolved phase, width of the hematites fluctuates 25 - 32 $\mu \mathrm{m}$.

Rajapur bay is dominantly made up of pure ilmenites with alterations along the boundaries, ilmenite + hematite and ilmenite + rutile (Fig.2 B). Ilmenite grains are irregular in shape and form. Exsolution intergrowths with lamellae of hematite are arranged along (0001), (0111) and (0112) planes of the host. The width of the hematite lamellae ranges $20-36 \mu \mathrm{m}$.

Vijaydurgh bay is consisting of ilmenite, ilmenite + rutile and ilmenite + hematite. Grains are sub-angular to sub-rounded in shape, showing exsolution with hematite and also replacement of ilmenite or ilmenite/hematite exsolution by sphene (Fig.3 O, P). The width of the hematite lamellae in the exsolved ilmenite of this bay varies $29-38 \mu \mathrm{m}$.

The width of the intergrown hematite lamellae of ilmneites derived from igneous rocks ranges up to $80 \mu \mathrm{m}$ whereas the width of $20-40 \mu \mathrm{m}$ is attributed to metamorphic rocks [1]. In the present study region, even though basaltic rocks are exposed adjoining the coast, the presence of fine lamellae $(20-35 \mu \mathrm{m})$ in the exsolved hematite phase points to the source, probably from metamorphic rocks rather than from hinterland basaltic rocks.

The purity of separated ilmenite concentrates has also been confirmed by Xray diffraction where ilmenites with different inter-planar intensity spacings are clearly demarcated. In addition, the intergrowths of ilmenites with rutile are confirmed at 27.1 to $27.6^{\circ}$, as ilmeno-rutile (Fig.4). Magnetites are also characterized by well developed secondary digitations at $100 \%$ peak, clearly indicating the exsolved phase of magnetite with hematite, rutile and ulvo-spinel (Fig. 5 ).

The opaque minerals, comprised of ilmenite and magnetite, do indicate the differential distribution in magnetite fractions, comprising magnetite, titanomagnetite and their intergrowths. Rajapur bay is distinguished from the rest in having higher pure magnetites. Ambolgarh, though adjacent to Rajapur, establishes a difference by higher titano-magnetite. Vijaydurg and Wada Vetye bays display a similar characteristics of magnetite and titanomagnetite. In the case of ilmenite, all the bays are noticed to have more or less uniform trend but for minor variations in their association with sphene, magnetite and rutile (Fig. 2 B). 

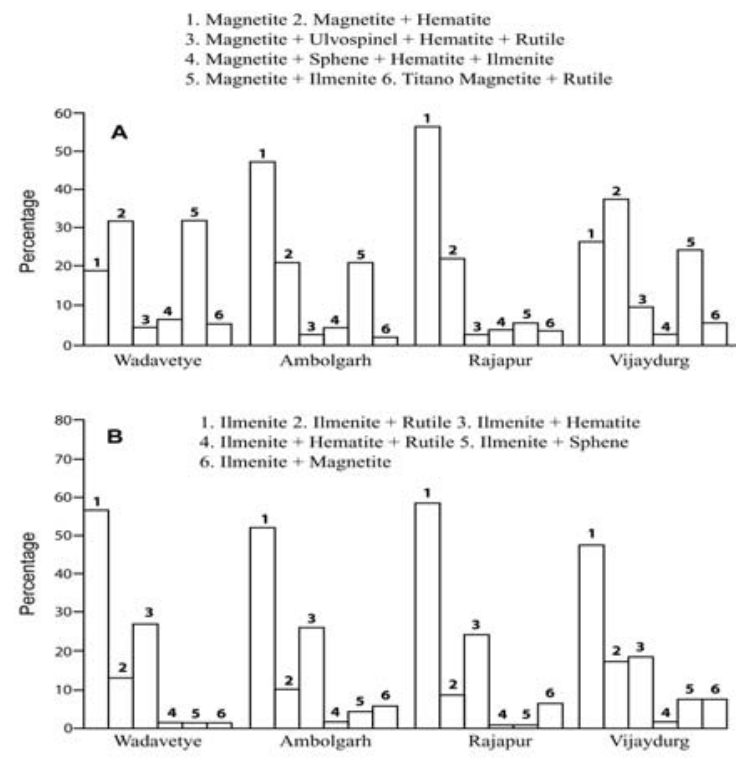

Fig. 2. Histogram of percentage distribution of Opaques
[A - Magnetite B - llmenite I \& their intergrowths.

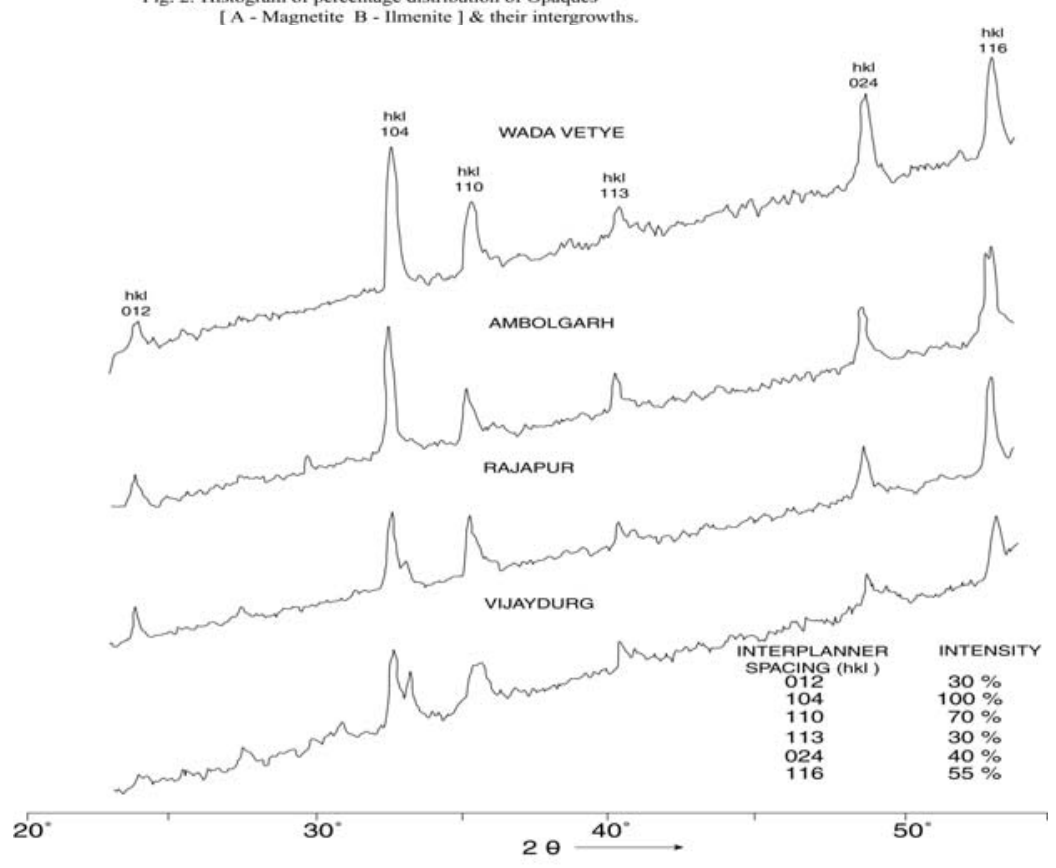

FIG. 4. X-RAY DIFFERACTOGRAM OF ILMENITE FROM BAYS. 

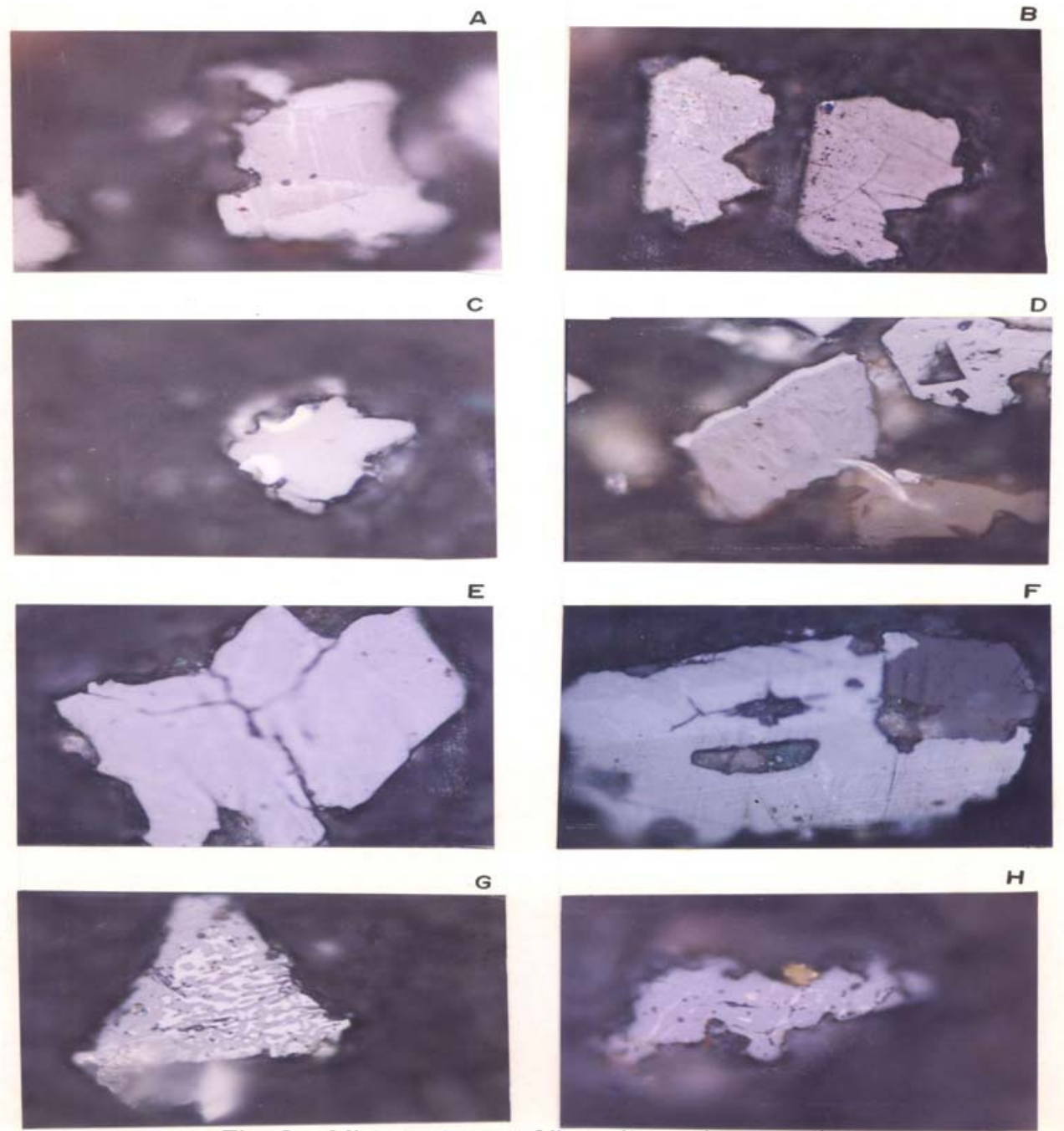

Fig. 3. Microtextures of ilmenite and magnetite

a. Exsolution of hematite with titano-magnetite in lamellar pattern and replacement of hematite along cleavage plane (Wada Vetye)

b. The exsolved magnetites with hematites

c. Irregular magnetite grains with martitisation along the border (Ambolgarh bay)

d. Titano-magnetite with ilmenite and white coloured martite along the border. Another titanomagnetite is also seen on the right (Ambolgarh bay)

e. Grain of pure magnetite with maghemite (Rajapur bay)

f. Intergrowth of ilmenite+magnetite with hematite. Replacement of hematite is also seen (Vijaydurg bay)

g. Graphic texture formed by magnetite with hematite (Vijaydurg bay)

h. Magnetite with hematite and alos whitest part of martite in the centre of the grain 

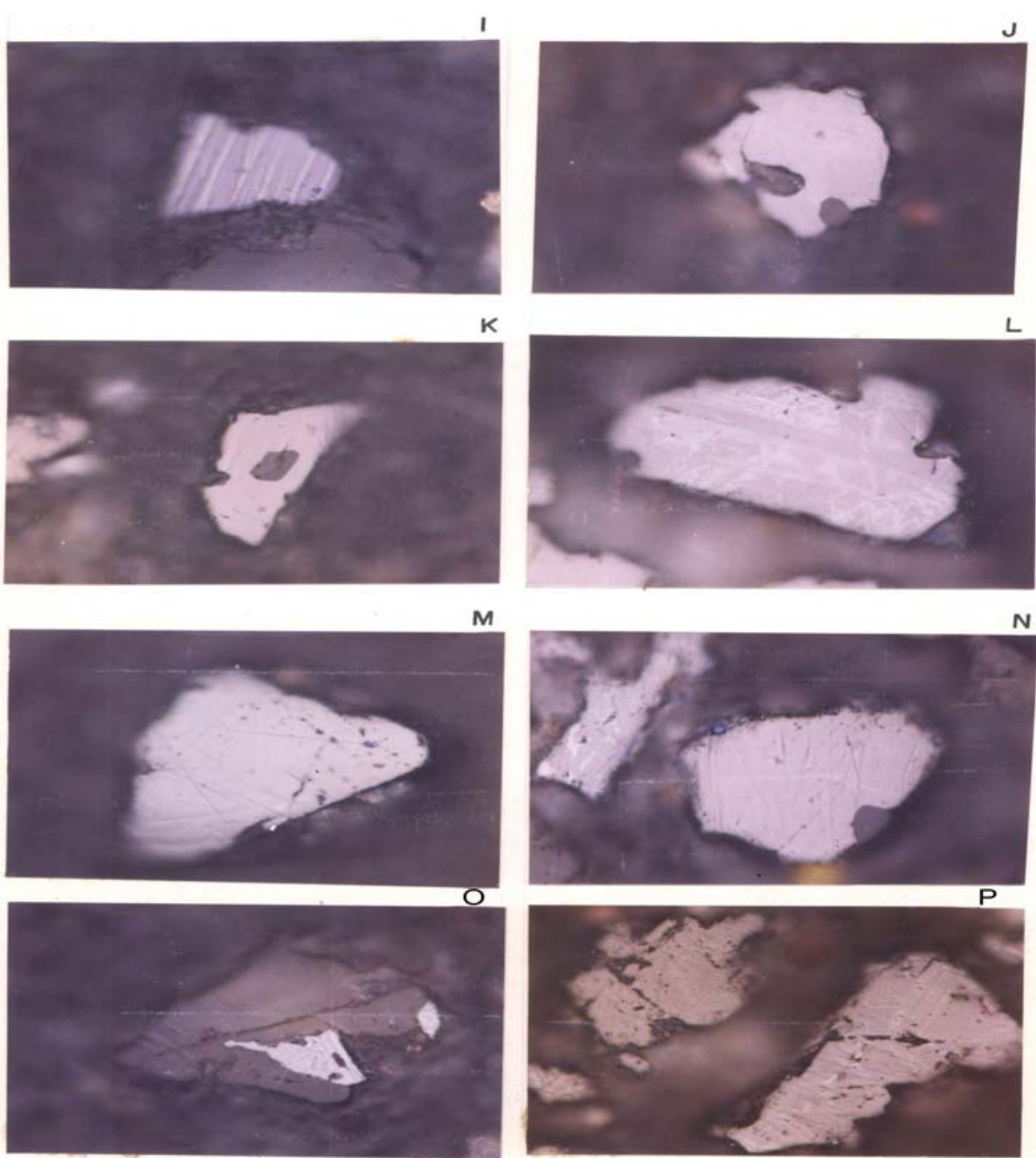

Fig. 3. Microtextures of ilmenite and magnetite

I. Seriate texture with alternate bands of hematite exsolved in magnetite. (Vijaydurg bay).

j. Replacement of magnetite along the borders by sphene and hematite patches (Vijaydurg bay)

k.Magnetite with inclusions of sphene and white streaks of hematite (Vijaydurg bay)

I.Ilmenite-magnetite grain with rutile needles and replacement texture of hematite along the cleaveages (Wada Vetye bay)

m.Rutilated ilmenite (Ambolgarh bay)

n. Ilmenite showing complete replacement by ilmenite-hematite phase by sphene (Vijaydurg bay)

o. Exsolved ilmenite with hematite and replacement of hematite along the rhombohedral edge (Vijaydurg bay)

p. Ilmenite replaced by hematite along the cleavages producing cloth texture. 


\section{MINERAL CHEMISTRY}

Ilmenite composition indicates a $\mathrm{TiO}_{2}$ variation from $38.41 \%$ to $45.20 \%$ (Table 2). Broadly, the chemical analysis has shown a close similarity among Ambolgarh and Rajapur bays' ilmenites whereas ilmenites of Vijaydurg and Wada Vete follow a similar pattern. Ambolgarh and Rajapur ilmenites register a lower $\mathrm{Ni}$, $\mathrm{Zn}$ and $\mathrm{Cu}, \mathrm{P}_{2} \mathrm{O}_{5}, \mathrm{CaO}, \mathrm{MgO}$ and $\mathrm{FeO}$ but higher $\mathrm{TiO}_{2}(43.57 \%$ - $45.80 \%$ ). The distribution of these elements along with $\mathrm{Fe}$ and $\mathrm{Mg}$ clearly attests to the nature of higher unexsolved ilmenites, ilmenite + rutile. In Wada Vetye and Vijaydurg bay, a negative correlation is established by $\mathrm{TiO}_{2}$ with $\mathrm{FeO}(\mathrm{r}=-0.77)$, $\mathrm{Cr} \quad(\mathrm{r}=-0.60)$. Successive stages of alteration of ilmenite have been attributed for the depletion of $\mathrm{FeO}$ [1]. The presence of altered ilmenites in Ambolgarh and Rajapur testify a higher percentage of $\mathrm{TiO}_{2}$. A higher amount of $\mathrm{FeO}$ (35.79\% - 36.26\%) in Wada Vetye and Vijaydurg is ascribable to higher presence of ilmenite - hematite exsolved phases.

Chemical analysis of magnetite indicates a distribution of $\mathrm{Fe}_{2} \mathrm{O}_{3}$ in Wada Vetye (Av. $58.25 \%$ ), Ambolgarh (Av. 54.33 \%), Rajapur (54.60\%) and Vijaydurg (54.43\%) (Table 3). A higher percentage at Wada Vetye and lower concentration at Vijaydurg, with almost equi-distribution in Ambolgarh and Rajapur can be earmarked to nature of magnetite intergrowth. While Wada Vetye displays more magnetite + hematite + ilmenite, Vijaydurg is dominated by pure magnetite. $\mathrm{TiO}_{2}$ deteriorates in the descending order from Rajapur, Vijaydurg, Wada Vetye to Ambolgarh. This can be ascribed to the differential replacement of mangnetite with rutile, ilmenite and sphene.

\section{RARE EARTH ELEMENTS}

Chondrite normalized REE pattern [14] of ilmenite shows enrichment of LREE (Table 4) over HREE (Fig. 6). The pattern shows increase in the elements according to the increasing atomic radius, suggesting that the LREE have undergone fractionation from HREE. A comparison with ilmenites of Manvalakurichi, India, where it is being commercially exploited [15] shows that ilmenite in the study area is rich in LREE as well as HREE. REE pattern of the ilmenites of the study area shows a negative Eu anomaly which could have been resulted due to any one of the following conditions either together or independently, i) melt effect, 2) crystallo-chemical effect, and iii) competing mineral effect [16].

The chondrite normalized REE pattern of magnetite shows that there is a well defined enrichment of LREE concentration (54.62 - 60.56 ppm) over the HREE concentrations (11.50 - $12.18 \mathrm{ppm})$. The ratio varies LREE/HREE from 4.74 to 4.94 (Av. 4.85). The profile (Fig.6) shows a distinct - Eu and Ce anomalies and the order of enrichment of the REE increases in the elements of increasing atomic radius. The enrichment of LREE in the magnetites could have been resulted due to the preferential incorporation of LREE relative to HREE formed during partial melting [16], 
A.R. Gujar, N. Angusamy, and G.V. Rajamanikam

Vol.6, No.1

Table 2:- chemical composition of representative ilmenite from the study area

\begin{tabular}{|l|l|l|l|l|l|l|l|l|l|l|l|}
\hline & \multicolumn{3}{|c|}{ WadaVetye } & \multicolumn{3}{c|}{ Ambolgarh } & \multicolumn{3}{c|}{ Rajapur } & \multicolumn{3}{c|}{ Vijaydurg } \\
\hline & V-105 & V-81 & Av. & A-60 & A-30 & Av. & R-15 & VD-64 & VD-15 & VD-39 & Av. \\
\hline $\mathrm{SiO}_{2}$ & 0.35 & 3.63 & 3.56 & 2.17 & 3.6 & 2.71 & 2.87 & 4.45 & 2.17 & 1.8 & 2.8 \\
\hline $\mathrm{Al}_{2} \mathrm{O}_{3}$ & 1.37 & 2.24 & 1.3 & 0.98 & 1.52 & 1.25 & 0.88 & 1.2 & 1.05 & 0.23 & 0.82 \\
\hline $\mathrm{TiO}_{2}$ & 40.39 & 35.54 & 38.41 & 43.95 & 43.32 & 43.57 & 45.85 & 30.72 & 46.6 & 43.2 & 40.17 \\
\hline $\mathrm{Fe}_{2} \mathrm{O}_{3}$ & 14.26 & 18.22 & 16.24 & 16.82 & 12.65 & 17.73 & 16.96 & 18.96 & 15.6 & 14 & 16.18 \\
\hline $\mathrm{FeO}$ & 35.92 & 36.61 & 36.26 & 31.65 & 29.52 & 30.58 & 30.55 & 38.9 & 30.95 & 37.52 & 35.79 \\
\hline $\mathrm{MnO}$ & 0.43 & 0.41 & 0.42 & 0.43 & 0.34 & 0.38 & 0.41 & 0.29 & 0.37 & 0.77 & 0.47 \\
\hline $\mathrm{MgO}$ & 2.04 & 1.87 & 1.95 & 1.66 & 1.15 & 1.4 & 0.66 & 2.71 & 1.04 & 0.82 & 1.52 \\
\hline $\mathrm{CaO}$ & 0.46 & 0.32 & 0.39 & 0.16 & 0.36 & 0.26 & 0.19 & 0.64 & 0.78 & 0.62 & 0.68 \\
\hline $\mathrm{P}_{2} \mathrm{O}_{5}$ & 0.18 & 0.26 & 0.22 & 0.19 & 0.11 & 0.15 & 0.2 & 0.24 & 0.31 & 0.23 & 0.26 \\
\hline $\mathrm{V}_{2} \mathrm{O}_{5}$ & 0.02 & 0.02 & 0.02 & 0.02 & 0.02 & 0.01 & 0.02 & 0.03 & 0.16 & 0.02 & 0.06 \\
\hline
\end{tabular}

Table 3:- chemical composition of representative magnetite from the study area

\begin{tabular}{|l|l|l|l|l|l|l|l|l|l|l|l|}
\hline & \multicolumn{3}{|c}{ WadaVetye } & \multicolumn{3}{c|}{ Ambolgarh } & \multicolumn{2}{c|}{ Rajapur } & \multicolumn{3}{c|}{ Vijaydurg } \\
\hline & V-105 & V-81 & Av. & A-60 & A-30 & Av. & R-15 & VD-64 & VD-15 & VD-39 & Av. \\
\hline $\mathrm{SiO}_{2}$ & 3.28 & 0.3 & 1.79 & 0.8 & 0.2 & 0.5 & 0.12 & 3.18 & 1.1 & 1.2 & 1.82 \\
\hline $\mathrm{Al}_{2} \mathrm{O}_{3}$ & 5.2 & 1.4 & 3.3 & 2.91 & 0.45 & 1.68 & 0.84 & 3.32 & 3.8 & 2.01 & 2.9 \\
\hline $\mathrm{TiO}_{2}$ & 12.45 & 17.96 & 15.21 & 15.3 & 14.62 & 14.96 & 16.78 & 13.36 & 16.05 & 16.74 & 15.38 \\
\hline $\mathrm{Fe}_{2} \mathrm{O}_{3}$ & 56.5 & 60.2 & 58.25 & 52.5 & 56.16 & 54.33 & 54.6 & 51 & 52.69 & 53.61 & 52.43 \\
\hline $\mathrm{FeO}$ & 18.07 & 15.92 & 16.99 & 23.16 & 22.33 & 22.74 & 23.4 & 24 & 20.43 & 22.47 & 22.3 \\
\hline $\mathrm{MnO}$ & 0.32 & 0.46 & 0.16 & 0.44 & 0.41 & 0.42 & 048 & 0.42 & 0.49 & 0.51 & 0.46 \\
\hline $\mathrm{MgO}$ & 1.28 & 1.8 & 1.29 & 2.99 & 3.27 & 3.12 & 2.85 & 1.51 & 1.25 & 1.48 & 1.41 \\
\hline $\mathrm{CaO}$ & 0.74 & 0.64 & 0.68 & 0.84 & 0.71 & 0.75 & 0.52 & 0.71 & 0.72 & 0.63 & 0.68 \\
\hline $\mathrm{P}_{2} \mathrm{O}_{5}$ & 0.21 & 0.36 & 0.28 & 0.4 & 0.48 & 0.44 & 0.28 & 0.55 & 0.41 & 0.18 & 0.38 \\
\hline $\mathrm{V}_{2} \mathrm{O}_{5}$ & 0.2 & 0.04 & 0.22 & 0.04 & 0.03 & 0.03 & 0.04 & 0.03 & 0.22 & 0.04 & 0.06 \\
\hline
\end{tabular}


which further indicate that the incorporation of lanthanides in the magnetite is not based on reduction in ionic radii. The observed Eu anomaly, in magnetites as well as in the non-magnetics, can be due to the prevalence of low pressure crystallization of plagioclase feldspar prior to magnetite crystallization from the melt [17]. This anomaly could be generated, due to the preferential uptake of Eu by other phases, crystallizing simultaneously along with magnetite (Complex mineral effect). The Ce anomaly implies conversion of $\mathrm{Ce}^{4+}$ to $\mathrm{Ce}^{3+}$ at the time of fractionation.

\section{MINERAL PROCESSING}

Titanium dioxide is by far the most important and intermediate product of the world titanium industry. The whiteness of titanium oxide and light scattering effect makes it as the only suitable pigment for paint, paper and rubber industries. Fine grained ilmenites can be used as a constituent of anti-corrosive paints as a substitution for graphite. Minimum purity for ilmenite is mineralogically $98 \%$ homogenous and chemically, it should contain $40-58 \%$ of titanium oxide. Enrichment of $\mathrm{TiO}_{2}$ in the ilmenites of the present study region, shows a close correlation with ilmenites of Canada, USA and Brazil where it is currently under exploitation. A higher concentration of $\mathrm{TiO}_{2}$ and $\mathrm{FeO}$ reveals that the ilmenites of the present study region can be exploited for application in paint industries.

Table 4 chemical analysis of REE and trace elements of the representative ilmenite, magnetite and Non-magnetites (values in ppm)

\begin{tabular}{|l|l|l|l|l|l|l|}
\hline & 1 & 2 & 3 & 4 & 5 & 6 \\
\hline REE & & & & & & \\
\hline La & 18.36 & 19.72 & 14.94 & 13.47 & 17.27 & 30.58 \\
\hline $\mathrm{Ce}$ & 27.54 & 26.56 & 26.09 & 23.77 & 30.09 & 52.89 \\
\hline $\mathrm{Pr}$ & 4.12 & 4.43 & 3.16 & 2.73 & 3.86 & 5.68 \\
\hline $\mathrm{Nd}$ & 16.82 & 16.13 & 14.38 & 12.48 & 16.78 & 27.27 \\
\hline $\mathrm{Sm}$ & 2.22 & 2.43 & 1.99 & 2.17 & 2.99 & 4.38 \\
\hline Eu & 0.65 & 0.53 & 0.65 & 0.38 & 0.88 & 0.8 \\
\hline $\mathrm{Gd}$ & 2.44 & 2.3 & 1.78 & 2.07 & 2.9 & 4.38 \\
\hline Tb & 0.52 & 0.43 & 0.55 & 0.41 & 0.62 & 0.83 \\
\hline $\mathrm{Dy}$ & 3.3 & 2.61 & 2.31 & 2.53 & 4.22 & 5.61 \\
\hline $\mathrm{Ho}$ & 0.81 & 0.72 & 0.67 & 0.56 & 1.07 & 1.46 \\
\hline Er & 3.25 & 2.68 & 2.13 & 1.8 & 3.35 & 5.56 \\
\hline $\mathrm{Tm}$ & 0.72 & 0.76 & 0.39 & 0.45 & 0.5 & 0.95 \\
\hline Yb & 5.72 & 5.34 & 3.17 & 2.73 & 4.58 & 6.86 \\
\hline Lu & 1.05 & 1.05 & 0.52 & 0.57 & 0.77 & 1.42 \\
\hline
\end{tabular}




\begin{tabular}{|l|l|l|l|l|l|l|}
\hline Trace elements & & & & & & \\
\hline $\mathrm{Sc}$ & 71 & 69 & 45 & 45 & 44 & 61 \\
\hline $\mathrm{V}$ & 129.09 & 1600 & 1989 & 2222 & 1167 & 1351 \\
\hline $\mathrm{Cr}$ & 210 & 249 & 266 & 331 & 268 & 267 \\
\hline $\mathrm{Co}$ & 121 & 123 & 134 & 139 & 82 & 102 \\
\hline $\mathrm{Ni}$ & 139 & 139 & 207 & 210 & 111 & 129 \\
\hline $\mathrm{Cu}$ & 354 & 314 & 718 & 886 & 815 & 809 \\
\hline $\mathrm{Zn}$ & 152 & 179 & 376 & 421 & 133 & 146 \\
\hline $\mathrm{Rb}$ & 2 & 1 & 3 & 2 & 3 & 2 \\
\hline $\mathrm{Sr}$ & 22 & 23 & 39 & 28 & 126 & 47 \\
\hline $\mathrm{Y}$ & 14 & 14 & 13 & 13 & 23 & 34 \\
\hline $\mathrm{Zr}$ & 3264 & 3111 & 1744 & 1607 & 1862 & 3455 \\
\hline $\mathrm{Nb}$ & 327 & 3 & 181 & 175 & 156 & 266 \\
\hline $\mathrm{Ba}$ & 25 & 35.67 & 30 & 29 & 25 & 30 \\
\hline $\mathrm{Hf}$ & 56 & 30 & 31 & 28 & 31 & 57 \\
\hline $\mathrm{Ta}$ & 11 & 1 & 7 & 6 & 5 & 10 \\
\hline $\mathrm{Pb}$ & 15 & 19 & 12 & 15 & 11 & 15 \\
\hline $\mathrm{Th}$ & 12 & 15 & 7 & 7 & 10 & 21 \\
\hline $\mathrm{U}$ & 1 & 1 & 1 & 2 & 2 & 4 \\
\hline
\end{tabular}

1 \& 2-Ilmenite (Wadavetye \& Vijaydurg)

3 \& 4 - Magnetite (Wadavetye \& Vijaydurg)

5 \& 6 - non-magnetite (Wadavetye \& Vijaydurg)

\section{CONCLUSION}

Characterisation of opaques, consisting mainly of magneites and ilmenties, under microscope shows the presence of both exsolved and replacement textures. In Ambolgarh and Rajapur, ilmenites of exsolved and replacement phases are abundant with alterations along the borders. Fine lamellae of exsolved hematite phase in the ilmenites of the studied region, points out the possibility of its derivation from metamorphic rocks, rather than from the exposed basaltic rocks. Ilmenite composition indicates a $\mathrm{TiO}_{2}$ variation from $38.41 \%$ to $45.20 \%$. Altered ilmenites account for higher percentage of $\mathrm{TiO}_{2}$ in Ambolgarh and Rajapur. REE studies show -ve Eu anomaly in the ilmenites, magnetites and non-magnetics, which could have been caused by melt effect, crystallo-chemical effect and competing mineral effect in the melt. Enrichment of $\mathrm{TiO}_{2}$ brings out that ilmenites can be exploited for converting them into synthetic rutile by sulphate processes.

\section{ACKNOWLEDGEMENT}

The authors are thankful to Dr.Satish Shetye, Director, NIO, Goa for providing permission to publish this work. This paper has NIO's contribution number. 


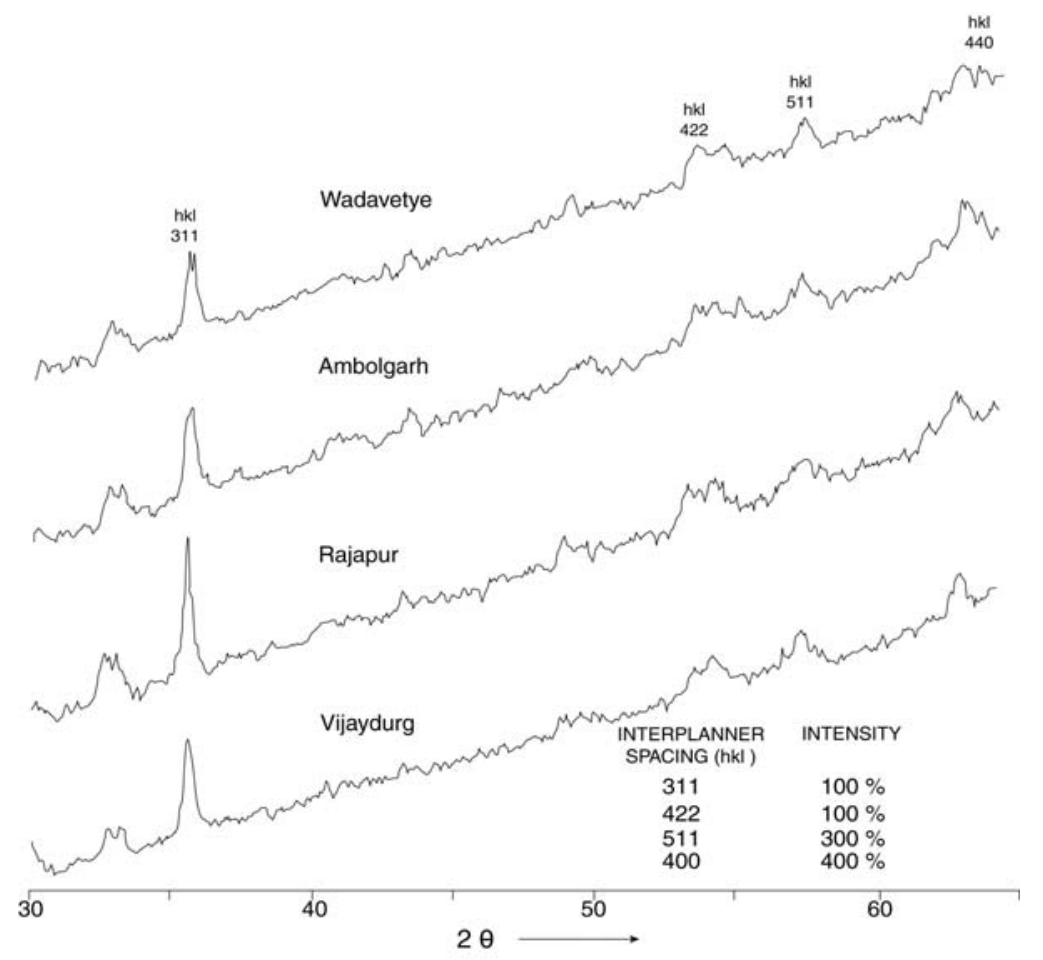

FIG. 5. X-Ray Differactogram of Magnetite from bays.
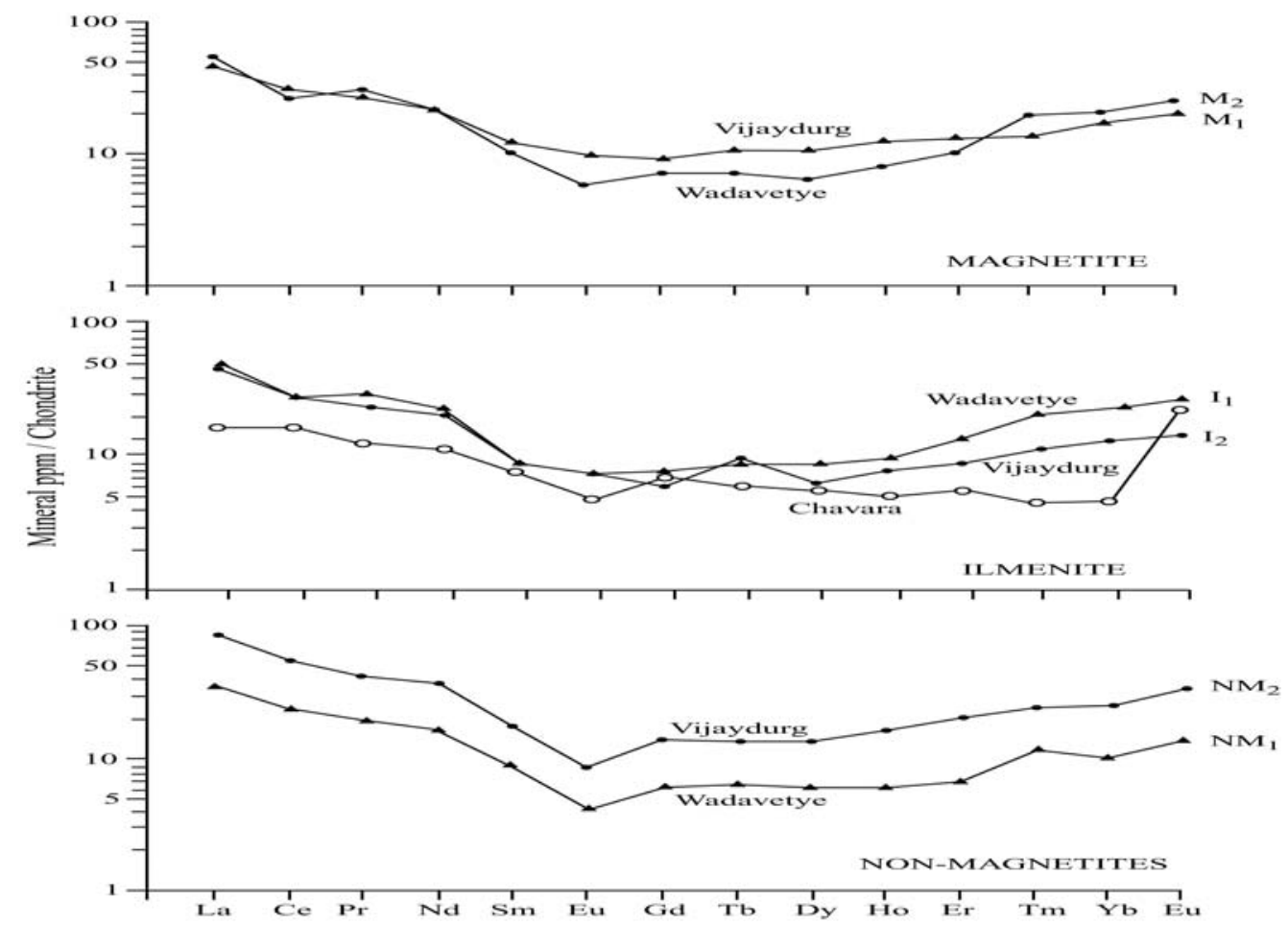

Fig.6. Chondrite normalised curves for representative Magnetite,

Ilmenite and Non Magnetites. 


\section{REFERENCES}

[1] Abhijit Basu and Emanuela Molinaroli., 1989, Provenance Characteristics of Detrital opaque Fe - Ti Oxide Minerals. J. Sedi. Petrol., Vol.59, pp.922-934.

[2] Harrison, R and Bartle, W.W. 2001, Titaniferrous feedstocks and zircon forecast outlook in 2005, Mieralex Agencies Pvt.Ltd, pp.90-293.

[3] Mir Azam Ali, Krishnan, S and Banerjee, D.C., 2001, Beach and inland heavy mineral sand investigations and deposits in India - An Overview, Special issue on Beach and Inland Heavy Mineral Sand Deposits of India. Exploration \& Research for Atomic Minerals, Vol.13, 21 p.

[4] Subrahmanyam, N.P., Rao, N.K., Narasimhan, D and Rao, G.V.U., 1982, alteration of beach sand ilmenite from Manavalakurichi, Tamil nadu, India, Jour.Geol.Soc.India., Vol.23, pp.168-174.

[5] Nair, G.A., Damodaran, K.T., and Suresh Babu, D.S., 1995, Mineralo-chemical analysis of ilmenite from the river Valliar and Manavalakurichi, Jour.Geol.Soc.India, Vol.6, pp.655-661.

[6] Rajamanickam, G.V. (1983) Geological investigations of offshore heavy mineral placers of Konkan coast, Maharashtra, India. Ph.D.Thesis, Indian School of Mines, Dhanbad (Unpublished) 258 p.

[7] Rajamanickam, G.V. 1997, Provenance of sediments from transparent heavy minerals in the inner shelf of Central Maharashtra, India, in the Second South Asia Geological Congress at Colombo, (Eds) Wijayananda,N.P., Cooray, P.G., and Peter Mosley,M Geological Survey \&Mines Bureau, Sri Lanka, pp.309-324.

[8] Rao, D.S., T. V. Vijayakumar, S. Prabhakar, G. Bhaskar Raju and T.K.Ghosh 2005, Alteration Characteristics Of Ilmenites From South India, J. of Minerals \& Metals Characterisation \& Engineering, 4, pp. 47-59.

[9] Milner, I. 1962, Sedimentary Petrography - George Allen \& Unwin Ltd - London.

[10] Shapiro, L. and Brannock, W.W., 1956, Rapid analysis of silicate rocks - US Geol. Survey Bull. 1036 C, 56 p.

[11] Shapiro, L. and Brannock, W.W., 1962, Rapid analysis of Silicates, carbonate and Phosphate rocks. U.S.Geol. Sur.Bull 1144.A, 53.

[12] Shapiro, L. 1978, Rapid analysis of silicate carbonate and phosphate rocks Revised edition. U.S.Geol.Surv.Bull. pp.1-75.

[13] Balaram, V., 1995, Development and trends in inductively coupled plasma spectrometry and its influence on the recent advances in trace element analysis. Current Science, 69, pp.640-649.

[14] Taylor, S.R., and McLennan, S.M., 1985, The Continental Crust: its composition and evolution. Blackwell Scientific Publishers, London.

[15] Thampi, P.K., Suchindan, G.K., Balasubramonian, G., Vasudevan, V.and Ramachandran, K.K., 1994, Evaluation of beach placers of SW coast of India in terms of REE and their geochemical significance, Unpublished Technical Report submitted to Dept.of Science and Technology, Govt.of India.

[16] Philpotts, J.A. and Schnetzler, C.C., 1972, Large fraction partitioning in igneous processes. 24th Int. Geol. Cong., pp.51-59. 
[17] Henderson, P., 1984, Rare earth element geochemistry (Developments in Geochemistry), Elsevier, Oxford. 